Ioana PAVEL

Faculty of Letters, Babeș-Bolyai University

Cluj-Napoca, Romania

indnpavell@gmail.com

\title{
LITERATURE AND MIGRATION: THE RE-PRESENTATIONS OF ITALY IN CONTEMPORARY ROMANIAN PROSE
}

Recommended Citation: Pavel, Ioana. "Literature and Migration: The Representations of Italy in Contemporary Romanian Prose". Metacritic Journal for $\begin{array}{lllll}\text { Comparative } & \text { Studies } & \text { (2020): }\end{array}$ https://doi.org/10.24193/mjcst.2020.9.10

\begin{abstract}
Thematised through the mechanism of fictionalization, migration is one of the common fields in which the social impact upon literature is visible on multiple levels. Discussions in which migration occupies a central place cover different areas of literary interest. Such areas are the status and the thematic preferences of the migrant writer, the "migration" (i.e. the circuit) of the book in the international space, and to the thematic reflection upon cultural, identity related, or psychological consequences of the phenomenon. The present study emphasises migration as a literary theme and insists on the reverberations that take place at the level of the narrative discourse (psychological print, narrative devices, real space vs. constructed space, subjective stamps on the re-presentation of the literary space etc.), starting from two case studies: The Little Girl Who Played at Being God by Dan Lungu, respectively Kinderland by Liliana Corobca. Besides the obvious sociological component, the novels share the interest in the psychological effects that the migration phenomenon has over the children. Their particular "voice" represents, in fact, a narrative device that both authors use in order to create an effect of authenticity.
\end{abstract}

Keywords: migration, psychological and sociological perspective, narrative device, Dan Lungu, Liliana Corobca. 


\section{...The Promised Land is at hand}

Intensified by the conditions imposed within the globalizing society with respect to both the number of migrants and the regions involved in the process (Anghel and Horváth 14), migration has become a common subject in the media discourse (especially due to statistics), in the sociological discourse (due to the social and psychological dimensions implied), in the legislative one (through the bureaucratic forms necessary for the "displacement" or for getting a job) and also in literary discourse (through fiction or new methodological approaches). A partially credible history of the phenomenon has not appeared yet, but the studies outline the "origin" of the migration theme in the Old Testament's command regarding the liberation of the Jewish people from the Egyptian slavery, and the promise of a "a land flowing with milk and honey", fictionalized and mythicized by the imagery of the entire Middle Ages and not only. Beyond different mutations and nuances of the representations in their historical trajectories, the extremely variable distance between the perceptible and the imagined appearance of the same spatial referent seems to remain unchanged, but impossible to neglect nowadays.

Literary thematised through fictionalization, migration not only keeps the social print in the limits of veracity, but also questions the transgression of borders between categories: "It is a time of the redrawing of maps, of intense deterritorializations and reterritorializations: people are passing borders, but borders are also passing people." (Frank 2). Moreover, the term "migrant" becomes "an umbrella concept that is able to include related concepts such as the exile, the expatriate, the refugee, the nomad, the homeless, the wanderer, and the explorer" (Frank 17). This fluidity of boundaries and categories allows literature that deals with these social, cultural and identity changes to function "as a form of mapping" (Tally Jr. 2) and facilitates their usage in discourse. Discussions regarding migration literature could cover recent topics of interest, varying from the status and the thematic preferences of the migrant writer, to the "migration" (i.e. the circuit) of the book in the international space, and up to the thematic reflection upon cultural, identity or psychological consequences of the phenomenon in fiction.

As a literary theme, migration is a phenomenon that is not only noteworthy in recent years, but also visible in the interest in the dynamics of the population over the twentieth century especially as a consequence of war and economical 
interferences: "the main protagonist in the twentieth century turned out to be the migrant. No longer to be looked upon as anomalous, migration has actually become, the norm and has resulted in a profound renegotiation of the concepts of identity, belonging, and home" (Frank 1). It "translates" the concern for the eccentric and the undiscovered into literature, but it could also gain autobiographical valences, both being according to "the function (...) of social representation of literature, namely that quality of the imaginary universe that offers a singular and unrepeatable answer to certain community-related problems, dilemmas, convulsions and anxieties" 1 (Cordoş 15). Thus, without underestimating or overestimating its aesthetic potential, literature can be read from a sociological perspective, reconsidering its force as a social barometer, as well as its capacity to insert in discourse both the image of the alterity and the prejudices concerning it.

In this context, the fact that contemporary writers appeal to such a theme is not surprising, rather it follows certain constructs that literary history and criticism have already investigated. After all the (re)orientations towards the West, transposed in fictions that mythicize the image of Western culture through the paradisiacal and redemptive dimension especially during the Communist regime, the Romanian postRevolution migration is marked by nomadism (Cordoş 149-151), and it orientates itself especially towards the Italian space. The fascination for Italy is not new in the Romanian literature. As shown by Sanda Cordoş, it is present since the very emergence of Romanian literature in the modern sense of the term at the beginning of the nineteenth century. This attraction for the Italian space could be observed on multiple levels, from that of real geography, to the "Italianating" tendencies, and up to the artistic representation itself in the so-called "thematised Italy", equally present in the writings of mid-nineteenth-century writers, in the interwar period, and in the post-war literature (Cordoș 107-108). The investigation stops at the latter period, favouring authors such as Adrian Popescu, Ruxandra Cesereanu, Ana Blandiana, Gabriela Melinescu, Radu Mareș, Florina Ilis. Regardless of period, Italy has been permanently associated with freedom, art, beauty, thus, with an ideal(ized) imaginary place, individualized by and through admiration, nostalgia, and dramatism. In light of recent literary research, we can add the "geocritical" reading of the Italian space of Alexandra Vrânceanu. Her study is dedicated to the cases of

${ }^{1}$ „funcția (...) de reprezentare socială a literaturii, adică acea calitate a universului imaginar de a da un răspuns unic și irepetabil unor probleme, neliniști, convulsii și angoase comunitare" (All translations of Romanian references are mine). 
Bujor Nedelcovici's book The wolf tamer and Dumitru Țepeneag's volume Maramureș, who both illustrate not only the effects of cultural and therefore, linguistic renegotiations or exchanges, but also the identity crisis caused by this phenomenon (Vrânceanu 83-101).

The novels The Little Girl Who Played at Being God (Fetița care se juca de-a Dumnezeu) by Dan Lungu (now at its third edition) and Kinderland (2013), by Liliana Corobca (bestseller of the publisher Cartea Românească, according to Bookfest 2013), propose a fictional revisiting of the phenomenon. They follow not only the cultural and identity related consequences of migration to Italy, or those regarding migrants' difficult adaptation, but also the consequences of them leaving home upon the family members remained behind. Presenting some psychological aspects, the novels use the child's perspective both directly and indirectly as a narrative mechanism. This technique helps to configure the drama experienced by the entire family, which was separated by the distance inherent in migration. The books depict the children's desperate attempts to picture Italy, the country that "took mom away" and reduced them to beings that only have basic primary needs to be met, as shown in Maslow's well-known hierarchy of needs.

\section{Unfulfilled promises, a game and more "Italies"}

Dan Lungu's text has a parallel structure in which the narrator is both omniscient and of authorial type. More precisely, the centre of orientation belongs to the character, not to the narrator (Lintvelt 48), the latter conceding some of his rights to the "voices" of the characters, namely the mother Letiția and her youngest daughter Rădița, equally assuming the function of representation and the interpretative one (Lintvelt 38). The author's background in sociology is visible in this point, as the interest in a sociological phenomenon is "migrating" through the rather unstable frontiers of literature.

In The Little Girl Who Played at Being God, the moment that triggered Rădița's imaginary constructions is precisely the announcement of her mother's departure to Italy:

the second day in the morning she had to go to Italy because she had found somewhere to work, it was very urgent, came out of nowhere, she's going to stay for a short period, until she makes enough money, after that they're all going to move back 
to the apartment (...) she'll have to be a good little girl, her mother will send her dolls and sweets, time will fly quickly, until it's summer or autumn already (Lungu 20)².

In order to supplant the impossibility to change her mother's decision to leave, the little girl finds a substitute, which helps her reconfigure the world through a compensatory game, namely by "playing God". The game reminds of the dialectical distinction often used in geo-critical approaches between voyeur who is the person who knows the city by roaming on street-level, and flâneur who is the one who creates the city by watching it from above, the so-called God's view (De Certeau 9193). Standing on the peak of the highest building which is the equivalent of the simultaneously isolating and depressing ivory tower, Rădița thinks she can "lead” the world, commanding predictable events that would take place in the near future:

On a bench, an elderly lady was sitting with a magazine in her arms, and the girl commanded whispering: read! and the lady started to read. A child the age of Năsturel was preparing his ball. He took a few steps back, and she commanded: shoot! So he shot. A bald gentleman was heading towards his car near the sidewalk, and she commanded him to open the door and enter, so he opened the door and got in. (...) Everybody obeyed without question. In fact, that was the game, that's what they're supposed to do, while she knew, in return, that she can't ask for everything. There's no purpose in ordering them to throw themselves in front of a car or to forget their wallets on the benches, they wouldn't do that. She too mustn't exaggerate. If she were to ask them to do harm, they wouldn't obey her. But she is only well-intended, because that's what mom and granny taught her. (...) How she would have commanded her mom to come back from Italy sooner, but the distance was cancelling her powers (Lungu 41) 3 .

\footnotetext{
2 ,a doua zi dimineață trebuia să plece în Italia, pentru că a găsit ceva de muncă acolo, era foarte urgent, se ivise pe neașteptate, va sta o perioadă scurtă, cât să facă rost de bani, apoi se vor muta cu toții înapoi în apartament (...) ea va trebui să fie o fetiță bună, îi va trimite păpuși și dulciuri, timpul va trece repede, va sta până în vară sau până în toamnă."

3 „Pe o bancă, o doamnă în vârstă stătea cu o revistă în brațe, iar ea îi porunci în șoaptă citește! și doamna prinse a citi. Un copil de vârsta lui Năsturel își pregăti mingea, își făcu vânt, iar ea îi porunci şutează! şi el trase. Un domn cu chelia se îndreptă spre maşina de lângă trotuar, iar ea îi porunci să intre și el deschise portiera și se băgă înăuntru. (...) Cu toții ascultau de ea fără să crâcnească. De fapt, chiar ăsta era jocul, asta trebuiau să facă, iar ea, la rândul ei, știa că nu le poate cere orice. Degeaba lear fi poruncit să se arunce în fața mașinii sau să lase portmoneul pe bancă, asta nu ar fi făcut-o. Nici ea nu trebuia să exagereze. Dacă le cerea să facă un rău cuiva, n-ar fi ascultat-o. Dar ea nu voia decât binele, fiindcă aşa o învățaseră mama și Buna. [...] Tare i-ar fi poruncit mamei să se întoarcă mai repede din Italia, dar la așa distanță nu avea nici o putere.”
} 
The paragraph emphasises both the compensatory function of the game, and the idea of its addressability towards all age categories: Rădița "commands" without such restraints, preferring other "rules" that she establishes according to some principles she learned in the family. The tragedy of the situation, that is the impossibility to "command" her mother's return, is hidden by the tolerance of some boundaries in the context of the game. These limits are the equivalent of a painful resignation, tolerance given by the uncontrollable physical distance. Thus, migration becomes an assimilable phenomenon due to a relativizing chronotope where the spatial and the temporal dimensions are subjectively implied. Her attempts to cancel this distance materialize in her thoroughly realised, detective-like plan to escape to Italy in order to meet her mother. Aware of the difficulties that she might encounter such as the weight of the luggage, the struggle with orientation, the careful preparations that must unfold under absolute secrecy hiding from her grandmother, the little girl thinks in mercantile terms both the outset and the overcoming of the obstacles: "Money can solve anything these days, that she knows for sure"4 (Lungu 140). Later, her resignation turns into disappointment: determined to surprise her mother, the little girl needs to gather enough money for a ticket to Italy. However, when she thinks she has reached the sum and asks Miron, a neighbour and friend of the family, to confirm, she finds out that her financial efforts are actually the equivalent of a pair of shoes. From this moment onwards, her quest to "escape" meets the actual tragic dimension, and she completely refuses to communicate. Shy and secluded, she withdraws more into herself, sometimes even refusing to talk to her mother.

The metonymical shift of the girl's mother into a voice is noteworthy in the novels of Dan Lungu and Liliana Corobca alike. She is no longer visually perceptible or imaginable: "Mom is the moist voice who's asking how-are-you-beloved? how-isyour-school-going? what-birthday-present-should-I-get-you? are-you-and-grandmagetting-along? (...) Mom's voice is sending money to rebuild my grandparent's old house (...) Mom's voice mails packages" 5 (Lungu 72-73). Regardless of her multiple attempts of involuntary memory, it seems that Rădița's imagination is no longer capable of finding the imaginative resources to rebuild the maternal figure: „Only the voice is left of mom. Her hands have disappeared, the swish of her dress, the rustle of

\footnotetext{
4 „Cu bani se rezolvă orice în ziua de azi, știa ea precis.”

5 „Mama e o voce umedă care o întreabă ce-mai-faci-iubita? ce-note-ai-mai-luat-la-școală? ce-cadousă-ți-iau-de-ziua-ta? te-înțelegi-bine-cu-Buna? (...) Vocea mamei trimite bani ca să refacă vechea casă a bunicilor [...] Vocea mamei trimite pachete la poștă”.
} 
her hair while combing in front of the mirror are there no more"6 (Lungu 106). The traumatic psychological consequences of the telephone scenes degenerate into the girl's categorical refusal to establish a proper communication with her mother, even when possessing the means to form a bond through internet video calls: „Three summers have passed since mother left and she didn't keep her promise to return for good, not even to come see her once. (...) She didn't even want to talk to her on the computer, once or twice, so at one point, grandma scolded her badly"7 (Lungu 284). These unfulfilled promises amplify the girl's reactions and her constant refusal to communicate. This changes in Liliana Corobca's case, where the mother returns home periodically, and this to-and-fro motion does not generate such vehement gestures.

Moreover, the ever-growing awareness of the missing mother generates even stronger emotional reactions from the girl. On the one hand, this both physical and emotional distancing from her mother, then also from her father creates a state of (un)acknowledged fear. This fact causes a series of nightmares in which the mother returns home, but the two of them cannot communicate through speech, only with the help of signs: mom "has forgotten the words" so that they can no longer communicate in Romanian. On the other hand, mom shifts into a grotesque-looking being, which deprives the girl of affective interaction: "mom's hands were brown up to the elbow and they smelled ugly, no one can bear standing in front of her, mother was sad and in tears, (...) all these were only in her dream, but the slight terror was prolonging"8 (Lungu 284).

Thus, the trance extends in the real life interfering with imaginary projections. In this sense, the scene in which Rădița is called by her sister Mălina and is invited over to dinner, also reveals how the little girl's imagination overlaps her unspoken desires by identifying her sister's projection with the absent mother:

as seen from behind and slightly against the light, Mălina could be easily mistaken with mother. The same waistline, the same gestures. For a moment, she was

\footnotetext{
${ }^{6}$ „Din mama nu mai rămăsese decât vocea. Mâinile ei dispăruseră, foșnetul rochiei și fâşâitul părului pieptănat în fața oglinzii nu mai erau nici ele.”

7 „Trecuse a treia vară de când mama plecase și tot nu se ținuse de cuvânt să se întoarcă de tot sau măcar să vină să o vadă. (...) O dată sau de două ori, nici n-a mai vrut să vorbească cu ea, la calculator, iar Buna a certat-o rău de tot”.

8 „mâinile mamei erau maro până la cot şi miroseau urât, nimeni nu voia să stea în fața ei, mama era tristă şi plângea, (...) toate astea erau numai în vis, dar spaima se prelungea şi peste zi”.
} 
convinced that she had awoken from a long, milky sleep in which her mother left for Italy and other rubbish, and now she's awakened to the true reality (Lungu 296)9.

The reference to Mălina's "facing the world" posture is quite obviously a connection to the artistic technique of the perspective, both from the viewpoint of the visual image's composition, and from the internal view which heads towards an object.

Rădița's traumatic experience of being left by her mother who works in Italy is accentuated by the polyphonic narrative game of the different "perspectives" on the subject. Beyond the already outlined aspects, Italy is for Rădița an undesirable paradise of sweets and of all the things that she cannot find in Romania. Italy is the loathed utopia that marked her childhood. One of the key-moments that highlight this image is that of receiving the "fruit flavoured lollipops" from uncle Miron, sent by his wife, aunt Aspazia, also from Italy:

Lollipops nowhere to be found in Romania, not even if you were to search all the shops one at a time. Since her departure, mother too has been sending whole bags and sachets full of sweets, chocolate of all sizes, candies (...), but none had the taste of uncle Miron's lollipops (Lungu 84) ${ }^{10}$.

This projection of an unwanted paradise is feeding the contradictory feelings she experiences. Italy is built through the little girl's perception of the country not only as a world of continuous material welfare, but also as a topos where her mother could be found and where she would like to reach. However, all her efforts to cancel the distance are counterbalanced by disillusionment.

One of the almost hallucinating episodes is when Rădița is visited by Ina, the girl's new deskmate after the changes made upon the teacher's decision not to put two students whose parents work abroad in the same desk. Ina accepts the invitation after two weeks of hesitations from her parents who "generally think badly of the children who live with their grandparents, while their parents are roaming the world

\footnotetext{
9 „privită din spate și ușor împotriva luminii, Mălina semăna perfect cu mama. Aceeași talie, aceleași gesturi. Pentru o clipă a fost convinsă că s-a trezit dintr-un somn lung, dintr-un vis lăptos în care mama ei plecase în Italia și alte aiureli, iar acum se trezise la adevărata realitate.”

10 „Acadele cum nu găseai în România nici să fi luat toate magazinele pe rând. De când plecase, și mama îi trimitea pungi și pungulițe cu bunătățuri, ciocolăți de toate mărimile și bomboane (...), dar nici una nu avea gustul acadelelor lui nenea Miron”.
} 
to get money" (Lungu 265) ${ }^{11}$. Ina expresses her admiration and even her envy for Rădița when analysing the things and clothes of her deskmate: "How good it must be to have your mother in Italy!" (Lungu 269) ${ }^{12}$. This is the moment when two perspectives collide: the internal perspective of the child traumatised by the mother's absence, which is insufficiently "mended" materially and the outsider's external, more superficial view lacking the experience of distancing from the family members.

Eventually, Dan Lungu's novel establishes a symbolic geography of the same space, which is mapped differently according to the subjective prints of those implied. Thus, we could speak of more "Italies": one perceived by the mother who sees herself forced to survive in a "foreign" country, one seen by the daughter who imagines the country as an intangible paradise, and yet another one as seen by the generation who despises it from the perspective of the effects that the phenomenon produces. In short, Dan Lungu's text generates several versions of the space it represents and it simultaneously establishes the coordinates through which this space becomes symbolic, memorable, or simply unavoidable on the more or less imaginary map of our representation of the world.

\section{Imaginary parents, a voice-mother and the eternal return}

In contrast to Dan Lungu's prose, which highlights the tragic dimension of the phenomenon through the parallelism between the perception of the mother and that of her daughter, Liliana Corobca prefers the implied narrative formula of the authorial type. Here, the centre of orientation belongs to the narrator-character (Lintvelt 48) as it renders the privacy of the child whose parents left to work abroad through the narrative voice of Cristina, a twelve-year-old girl forced to stay at home and raise her younger siblings. In fact, one of the weak aspects claimed by the literary critics was precisely the very mature, therefore, unreliable voice of the girl who experienced a precocious maturity:

the voice of the writer makes its way through that of the narrator. She cannot even help reflecting upon migration, since the author herself lived in a Moldavian village and notices in detail all the changes that have occurred in the rural Romania after the

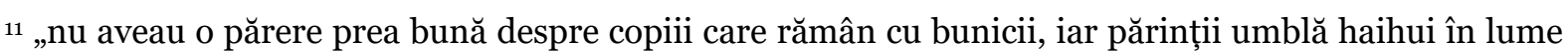
după bani”.

12 „Ce bine-i să ai mamă în Italia!”.
} 
revolution. These fragments and details are so delicately approached that we overlooked their unreliability (Bădică 2013) ${ }^{13}$.

What the critics seem to neglect is the fact that this early growing up is debatable from a psychological and a sociological point of view. In short, the early coming-ofage process is tied to the forced education that imposes the adaptation to a new context of living. Children and teenagers coming from disadvantaged environments prove most of the time an unusual maturity, simultaneously doubled by an acute emotional vulnerability. Such situations are represented in the novel too.

This time, the scene of leaving does not take place in the present of the narration anymore. Consequently, the reactions of the children are not illustrated directly, but exclusively through Cristina's remembering:

Mom only wanted two children. It was dad who wanted Marcel. She said: we can barely feed these two. Dad said, let's have one more child, I'll go to Iakutia to work, and I will get money to raise the children! (...) At the beginning though, it wasn't dad who brought the money, because he was gaining less and had debts to pay back. Then, a relative from Italy told mom: come here, a family is hiring, they pay well; if you don't want it, a hundred Moldavians are fighting to get here... My mom consulted with my dad, then with me and said she's going to leave for a year or two, until dad pays his debts. Then she left, and those one-or-two years never ended (Corobca 22) ${ }^{14}$.

The girl seems to have the right to express her opinion about her mother's decision. However, as in Dan Lungu's novel, the promise of return is always postponed. A so-called "homecoming migration" project (Sandu 109) can be observed in the texts of both authors. This project is visible in the cases of the persons who perceived departure like a rupture inside the family, and was negatively viewed by the other members left at home (Sandu 15-16). In the absence of the parents, Cristina becomes a sort of "surrogate mother" (Neagoe 2013) for her

\footnotetext{
${ }^{13}$ „vocea scriitoarei 1̂și face loc printre cea a naratoarei. Nici nu se poate abține să nu reflecteze asupra migrației, de vreme ce ea însăși a trăit într-un sat din Moldova și observă în amănunt toate schimbările care au intervenit în mediul rural după revoluție. Sunt fragmente și detalii atât de fin puse sub lupă încât am trecut cu vederea neverosimilitatea lor”.

14 „Mama a vrut numai doi copii. Pe Marcel l-a vrut tata. Ea a zis: abia pe ăștia doi avem cu ce-i hrăni. Tata a zis, las' să mai fie un copil, că mă duc eu în Iakutia, la muncă, și fac bani să ținem copiii! (...) Dar la început nu aducea tata bani, că primea mai puțin și avea de întors datoriile. Atunci un neam din Italia i-a zis mamei: hai, vino aici, că s-a eliberat un loc la o familie, plătesc bine; dacă nu vrei, o sută de moldoveni se bat să ajungă aici... Mama s-a sfătuit cu tata, apoi cu mine și a zis că pleacă pe un andoi, până își dă tata datoriile. Și a plecat, iar acel un an-doi nu se mai termină”.
} 
brothers, Dan and Marcel. She tries to compensate for their affective lack, but is not able to do so for herself:

One of them cries, the other wants food and flips everything around the kitchen in search of sugar. (...) They also want someone to spoil them a little, someone to notice them. And so do I, even though I'm older. I also want a mother by my side to cook for me and wash my dresses. And to iron them (Corobca 23) ${ }^{15}$.

One of the most significant consequences of the mother's departure to Italy is the children's imaginary reconstruction. The example of their father who is "mean”, aggressive, and who comes back home and physically abuses his offspring is a way of autosuggesting resignation yet hoping that the distance could be negated to some extent emotionally speaking: "See now, fool, what a father does? And you're sitting here crying day and night. Is it a dad you want, to walk around with blood coming out of your head and nose, to hide hungry and beaten at your neighbours?"16 (Corobca 33). Moreover, the father's example is also a strategy of counterbalancing the image of a "good" mother: "You can find as many bad fathers as you wish, because nearly all of them are drunkards beating their children. (...) Yet bad mothers are nowhere to be found" (Corobca 45-46) ${ }^{17}$.

The aggravation of parental deficiency can also be spotted in the ludic dimension. The game becomes, just like in the case of Dan Lungu, a compensatory space for the psychological needs of the children. They play the "perfect family" as it was idealized by the author:

Sometimes we have a concert on Sundays, we play family. I'm dressing up in your clothes, those who fit of course, they're a little large, but next year they're going to fit just right. Dan, who is the father, is floating in all of dad's clothes, and he wants to give up dressing in pants and shirts that are too large, because he cannot move, and we're laughing out loud when he waves his long sleeves or when his pants drop. (...)

\footnotetext{
15 „Unul plânge, altul vrea de mâncare și răstoarnă totul prin bucătărie, în căutarea zahărului. (...) Vor și ei să-i alinte cineva, să-i bage în seamă. Și eu vreau, chiar dacă-s mare. Vreau și eu o mamă alături, să-mi facă de mâncare, să-mi spele rochiile. Și să le calce.”

16 „Vezi, măi prostule, ce face un tată? Iar tu bocești zi și noapte. Tată îți trebuie, să umbli cu capul spart, cu sânge în nas, flămând și cârpit și să te ascunzi pe la vecini?”

${ }_{17}$ „Exemple de tați răi găsești câte vrei, că-s cam toți bețivi și toți își bat copiii. (...) Mamă rea nu am găsit."
} 
We smell the clothes. The hat smells like dad and the dresses smell like mom. $(\text { Corobca 47) })^{18}$.

In order to reconstruct the parents' image or at least their perception, the deceitful and distorting visual sense which - in Dan Lungu's case, generates the grotesque - is replaced by the olfactory one. This recognition of the parents by smell is nothing but another proof of their absence, masked by the game's implied simulacrum. Although this game should use all its possible creative resources, the absence turns into ordinariness and into a factor which blocks the girl's imagination resources in relation to the well-known typical reality of a family: "I can't even picture what's like to stay at home with a mother or a father. Imagine them washing your clothes, doing the cleaning, cooking, while you're allowed to waste time."19 (Corobca 56). Moreover, the idea of a game, which is encompassed in the title of the book, is also a cultural reference: the humanitarian support offers the school little boxes with Kinder eggs: "I always thought that kinder means egg. Then a foreign child told us it means child and then taught us the kinderland game, namely children having to play adults." 20 (Corobca 141). Kinderland becomes not only their favourite tragic rather than comedic game, but also another method to substitute the image of a separated family, adapting it to their situation and playing

[a] sort of family kinderland. I'm the mother usually, Dan is the father, and Marcel, the baby. Lately, however, Marcel doesn't want to be the infant anymore. I can cry beautifully, just like a baby: want milk!, want baby bottgles!, and Marcel is melting of delight (Corobca 145) ${ }^{21}$.

\footnotetext{
18 „Duminica facem concert uneori, ne jucăm de-a familia. Eu mă îmbrac în rochiile tale, care îmi vin, un pic sunt cam largi, dar la anul îmi vor fi tocmai bune. Dan, care e tata, plutește în toate hainele tatei şi renunță să îmbrace pantaloni și cămăşi prea mari, că nu se mai poate mișca și noi murim de râs cum fălălăiește cu mânecile prea lungi sau cum îi cad pantalonii (...) Mirosim hainele. Pălăria miroase a tată și rochiile a mamă."

19 „Nici nu-mi imaginez cum e să stai acasă cu mamă și cu tată. Să-ți spele ei hainele, să facă ei curățenie, mâncare, iar tu să tai frunză la câini.”

${ }_{20}$ „Credeam că kinder înseamnă ou. Apoi un copil străin ne-a spus că înseamnă copil și ne-a învățat jocul de-a kinderlandul, adică cei mici se joacă de-a cei mari.”

${ }^{21}$ „Un fel de kinderland în familie. Eu sunt mama, de obicei, Dan, tata, iar Marcel, cocuța. În ultimul timp însă, Marcel nu mai vrea să fie cocuța. Eu plâng foarte frumos ca un bebeluș și zic: vleau lapte, vleau bibelon, iar Marcel se topește de încântare.”
} 
The mother is metonymically reduced to the status of "voice" for the children in Liliana Corobca's novel too. Depending on age, communication is (de)constructing itself on more than one layer as the children converse by phone in descending order:

Mom is asking me what I have cooked and if there are food supplies left, if nothing is hurting us, if someone hit us or called us names, if any relative has brought us something good to eat, if our clothes are clean, if the washing machine, the fridge or the TV aren't broken, if the house is tidy. After that it's Dan's turn, who tells her what clothes or toys he wants mom to buy him, who else beat him (if it happened) and he always tells mom somewhat somewhere is hurting (...) I can't figure out what Marcel and mom are talking about, I mean what mom is telling Marcel (...). Marcel, who knows all the words and never shuts up that you have to yell at him "quiet, you chatterbox", but who only says mama mama mama while on the phone. All his vocabulary shrinks to this one word, which he utters on all tones, as if he were singing, and we leave his side, so we wouldn't burst into tears (Corobca 135-136) ${ }^{22}$.

Once again, the free, indirect narrative style represents the discursive mode through which justifications are linked without being included into a logical argumentation (in the case of Cristina). The communicative regression in the example above is the expression of unconscious suffering in the mind of the children. Moreover, another argument for the girl's "unreliable" maturity is evident in her mother's persistence to teach her daughter to play the maternal role.

Although waiting is one of the forces that animate the lives of the children, it ends up being compared to a virus, which, paradoxically, instead of afflicting, is "cured” when the parents come back: "Dan's fever and coughs were suddenly healed when mom returned home. (...) Our parents need only come home and we are completely cured, all our diseases" (Corobca 186) ${ }^{23}$. The eternally promised return is the reason for the psychological metamorphoses of the children into adults only to

\footnotetext{
22 „Pe mine mama mă întreabă ce mâncare am făcut și dacă mai avem provizii de alimente, dacă nu ne doare nimic, dacă ne-a bătut cineva sau ne-a poreclit, dacă vreo rudă ne-a mai adus ceva bun de mâncat, dacă avem haine curate, dacă mașina de spălat, frigiderul sau televizorul nu s-au stricat, dacă este curățel în casă. Apoi îi vine rândul lui Dan, care-i spune ce jucării sau ce haine mai vrea să-i cumpere mama, cine l-a bătut (dacă s-a întâmplat) și întotdeauna îi spune mamei că undeva ceva îl doare (...) Nu știu ce vorbește Marcel cu mama, adică ce-i spune mama lui Marcel (...) Marcel, care știe toate cuvintele și vorbește fără încetare, de trebuie să te răstești la el: taci, măi moară stricată, la telefon nu zice decât mama. Tot vocabularul lui se reduce la acest cuvânt, pe care îl rostește pe toate tonurile, de parcă ar cânta, iar noi plecăm de lângă el, ca să nu izbucnim în plâns". ${ }^{23}$ „Lui Dan i-au trecut și febra, și tusea, când a venit acasă mama. (...) E suficient ca părinții să vină acasă și ne vindecăm pe loc, de toate bolile.”
} 
eventually regain their right to be children: "We're growing old because of so much mature and responsible waiting and we are children again when mom returns home" (Corobca 186)24. The suffering of the separation is experienced "sequentially", because the children's mother in Liliana Corobca's novel returns periodically in contrast to Letiția, Dan Lungu's character who always promises to return but never does:

When mommy returns, she always asks what mommy's children want to eat. (...) Mommy's making a lot of food, which she later pours in tiny sachets and stores them in the freezer. After leaving again, we open them one by one. [...] Mom is working so hard when she comes home, that I think she rests only when back to Italy, even if there is a lot to work there too, according to her. (Corobca 138).

Compared to Dan Lungu's, Corobca's novel brings to light differences between the various needs in a much more explicit manner. By contrast to the physiological, primary, immediate needs, which are generally satisfied, the spiritual, psychological needs are not met and cannot be compensated for through other resources, as the depressive "for no good reason" episodes prove it. The character's emotional vulnerability is obvious: "I usually don't cry, but when it happens, I want to hide somewhere in a corner so my brothers won't see me. I know that I have no reason, I have nothing to cry for (...). So what if I'm weeping a tiny bit with no reason?" (Corobca 62) 25 .

The tragic and impersonal solution of the social worker who offers the children personal development books is blameworthy from the point of view of the narrator, and of the author implicitly. Not even recollection could "save" the identity of the family and of the children who no longer remember "what it means to live in a family, to have a mom and a dad by your side" (Corobca 62) ${ }^{26}$. The author's real and efficient solution is that of the reunited family, unaffected by the consequences of the globalizing society.

Although she is also dreaming of reaching Italy, Cristina's reasons are entirely different from Rădița's. The former wants to become a stewardess and she analyses

\footnotetext{
24 „Suntem îmbătrâniți de atâta așteptare responsabilă și matură și redevenim copii când vine mama.” ${ }^{25}$ „Eu nu plâng deloc niciodată, cui i-ar folosi? (...) Nu plâng, dar îmi vine uneori și atunci vreau să mă ascund în vreun colț, să nu mă vadă frații mei. Știu că nu am niciun motiv, nu am de ce plânge (...) Și ce dacă o să plâng și eu olecuță fără motiv?”

${ }^{26}$ „ce înseamnă să trăiești în familie, să ai alături tată şi mamă”.
} 
the problem of departure in mercantile terms. She is already picturing herself working in such an unknown and detested space, but which possesses its fair share of future opportunities, which are impossible to reach under the present circumstances:

"I could have easily taken care of a baby for 1000 euros a month. Here I'm taking care of two and what's the reward? I would have made a lot of money in Italy and I would have returned home to marry Fedoraș or stayed there, going to a prestigious school of «stewardesses»" (Corobca 118) ${ }^{27}$.

This projection of the "afar" is constructed progressively: the native space, "their" village is "the most beautiful in the world" (Corobca 193) ${ }^{28}$. This enables the girl's imagination and, thus, existence to create a secure space, which encompasses not only the family, but also the community:

\begin{abstract}
"There has to be a village just for us, with his own laws, with a life that's inaccessible and unknown to others. Where life flows beautiful, bountiful, merciful, without evil, longing or waiting. A village of good children. See, I mentioned «good». Not a simple village of the children, for that already exists. Every village of Moldavia, the whole country actually is a village of the children... Especially if we count the senile elderly. Men and women, normal, healthy, able to work and willing to live in the village are a rarity, a minority. The children's Moldavia. This sounds very beautiful. We're building a bright future for our children. Yes, only that we're doing it in Spain, Italy, Russia, because in the Czech Republic we've already built everything and workers are not needed anymore. There's a crisis going in Spain right now. Those whose parents are in Spain rejoiced. Crisis - the magic word which means parents returning to their home, to their children. But none returned" (Corobca 146) ${ }^{29}$.
\end{abstract}

\footnotetext{
${ }^{27}$ „Aș fi avut și eu grijă de un copil și aş fi primit 1000 de euro pe lună. Aici am grijă de doi și care-i răsplata? În Italia aș fi făcut mulți bani și m-aș fi întors acasă, să mă mărit cu Fedoraș ori aș fi rămas acolo, la o școală prestigioasă de «stewardese»."

28 „cel mai frumos din lume”.

29 „Trebuie să existe un sat doar al nostru, cu legile lui, cu viața lui inaccesibilă și necunoscută celorlalți. Unde viața să curgă frumos, darnic, milostiv, fără răutate, dor și așteptare. Un sat al copiilor buni. Vezi, am spus «buni». Nu doar satul copiilor, care deja există. Fiecare sat din Moldova e un sat al copiilor, întreaga țară... Mai ales dacă socotim și bătrânii, căzuți și ei în mintea copiilor. Bărbații și femeile, normali, sănătoși, apți de muncă și care să trăiască la sat, sunt o raritate, o minoritate. Moldova copiilor. Sună foarte frumos. Construim un viitor luminos pentru copiii noștri. Da, numai că1 construim în Spania, Italia, Rusia, că-n Cehia am construit deja totul şi nu se mai cer constructori. În Spania, de fapt, e criză. Copiii cu părinți în Spania s-au bucurat. Criza - cuvântul magic, care înseamnă întoarcerea părinților acasă, la copii. Dar nu s-a întors niciunul.”
} 
This fragment is most frequently summoned when arguing the unreliability of the narrative voice disregarding the creative resources of the infantile imagination. Beyond the idealism of the paragraph, we notice how the space is reconfigured at a cognitive level. The resulting map is not a visual one, but is rather a subjective construct, which depends on the context in order to become significant and intelligible. Hence the writer assumes a mapmaking role (Tally Jr. 54).

While Dan Lungu's novel is suspended in uncertainty regarding the mother's return, Liliana Corobca's marks another kind of incertitude, namely that of the "correct" feeling that Cristina should have when facing the changes that she has been waiting for all these years her parents were abroad: "I got a phone call from Lucian. He knew that nobody would tell me. Grandma died yesterday morning... I'm crying and I don't know if it's out of grief, or out of joy because, at last, my mom and dad will return" (Corobca 197)30.

\section{Conclusions}

The two novels render the different intensities and tensions identified inside families affected by migration. Both texts are aesthetically configuring one of the acute and tragic dynamics of contemporaneity: the "exodus" of the mature population. This topic is invisibly tied to the social perception of the migrants, to the psychological consequences especially on the children in the family left behind, as well as to the insufficient importance of the physiological needs, neglected in the detriment of the psychological ones (according to Maslow's hierarchy of needs). Eventually, both novels succeed in bringing the reader in the intimacy of the discussed characters, while they also question one of the most acute consequences of the globalization phenomenon. Considering the force of literature to present social problems through literary discourse, these two novels demonstrate how contemporary prose benefits from the interference with migration, changing it into the consciousness of the children whose "voices" remain striking references in the recent literary history.

\section{References:}

Anghel, Remus Gabriel, and István Horváth (coord.). Sociologia migrației (The Sociology of Migration). Polirom, 2009.

30 „Am primit un telefon de la Lucian. Ştia el că nimeni nu mi-a zis. Bunica a murit ieri dimineațăa...
Plâng si nici nu stiu dacă de jale din cauza bunicii sau de bucurie că, în sfârșit, mama și tata vor veni”. 
Bădică, Eli. "Moldova copiilor din «Kinderland»-ul Lilianei Corobca” ("The Moldavia of Liliana Corobca's «inderland»"), 06.06.2013, https://www.bookaholic.ro/moldova-copiilor-din-kinderland-ul-lilianeicorobca.html / Accessed 5 September 2019.

Corobca, Liliana. Kinderland. Polirom, 2015.

Cordoș, Sanda. Lumi din cuvinte. Reprezentări și identități în literatura română postbelică (Worlds in Words. Identities and Representation in the Post-war Romanian Literature). Cartea Românească, 2012.

De Certeau, Michel, The Practice of Everyday Life, translated by Steven Rendall. University of California Press, 1984.

Frank, Søren. Migration and literature: Günter Grass, Milan Kundera, Salman Rushdie, and Jan Kjærstad. Palgrave Macmillan, 2008.

Lintvelt, Jaap. Incercare de tipologie narativă. Punctul de vedere (Attempts on Narrative Typology. The Point of View), translated by Angela Martin. Univers, 1994.

Lungu, Dan. Fetița care se juca de-a Dumnezeu (The Little Girl Who Played at Being God). Polirom, 2014.

Sandu, Dumitru. Lumile sociale ale migrației românești în străinătate (The Social Worlds of Romanian Migration Abroad). Polirom, 2010.

Tally Jr., Robert T. Spatiality. Routledge, 2013.

Vrânceanu, Alexandra. "Letteratura transnazionale e romanzi di scrittori rumeni migranti”, in Nicoleta Neșu (ed.), Il romanzo rumeno contemporaneo (19892010). Teorie e proposte di lettura, Roma, Bagato Libri, 2010, pp. 83-101. 